\title{
Family Values, Social Capital \\ and Contradictions of American
}

\section{Modernity}

\author{
Philip Webb
}

\begin{abstract}
Contemporary American social and political discourses have integrated concerns about family values into the realm of debates about the associational life of social capital. In these discussions, theoretical and historical confusions about the relations between family and civil society run rampant. In this article, I first bring theoretical clarity to these social structures and the type of relations upon which they are predicated and, second, briefly historicize the relationships between an American idea of family and civil society. By tracing changes in popular understandings of family and civil society, I demonstrate that the modern family values movement spurns its Victorian roots by maintaining the nostalgic language for a life and family of old built around a Christian home, while embracing means and institutions, and even more importantly, a form of family, which belies the nostalgia. The family has now become an institution or association which can be sustained through instrumental interventions; it is no longer to do with the organic relations of sentiment remaining from some long-faded Gemeinschaft. The family and the Christian home ideal, which were at the center of American critiques of modernization, have ceased to be.
\end{abstract}

\section{Key words}

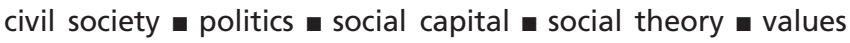

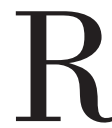

ECENT AMERICAN concerns about family values have expanded into the realm of debates about the associational life of social capital. ${ }^{1}$ In these discussions, confusions about the relations between family and civil society run rampant. Much of this new discourse erroneously posits that social capital reinforces community and family. The effort to assimilate the concern for family with social capital obscures not only

- Theory, Culture \& Society 2011 (SAGE, Los Angeles, London, New Delhi, and Singapore), Vol. 28(4): 96-123

DOI: $10.1177 / 0263276411404906$ 
difference but outright antagonism. Over the last century, dominant conceptions of family have transformed; from a site of affect to be protected from the vagaries of the outside world, the family has become a modern, transactional institution. I aim to disentangle confusions prevalent in this discourse of family and social capital through a two-pronged approach: first, to bring theoretical clarity to these social structures and the type of relations upon which they are predicated, and, second, to briefly historicize the relationships between an American idea of family and civil society. I frame this discussion primarily with two important (and representative) texts - one from the turn of the last century and a second from the turn of the recent one, with some important intervening texts - to chart the transformations in the relationship between family and civil society.

With the first text - Jacob Riis's Peril and Preservation of the Home (1903) - we will show the fin-de-siècle antagonism between family and the associational life of civil society, which has in some circles come to be called social capital in more recent decades. This antagonism emerged in response to the social changes spawned by urbanization. Riis expresses the concerns of a middle class faced with urbanizing social upheaval. His concerns about disintegrating social structures and the supporting value systems crystallized around the family, of which he spoke as if it were the last remnant of the organic bonds of community.

Carrying the then heavy photographic equipment through tenements, beer dives, police wards and other poverty-stricken nooks, Riis gave a face to poverty like no one before him. Illustrating his stories (with photographs and drawings) and showing magic lantern images (a proto-slide projection) on his cross-country treks for lecture series, he sketched poverty with words and pictures, which gave his pleas for reform a certain vitality and urgency. He trudged alongside a young police commissioner on raids of crime dens, rat-infested slums and illegal liquor houses, and so immediately drew political attention to his efforts and elicited instantaneous municipal response. His close relationship with Commissioner Roosevelt, who later became Governor, Vice-President and then finally President - thanks to an anarchist who assassinated President McKinley - gave nationwide political and popular reach to Riis's efforts. (He was offered and declined a Caribbean ambassadorship as thanks for his years of tireless reform efforts.) Riis served on innumerable panels, commissions and other instruments of reform, and his work moved from documentary description to normative exhortation. He was influential as an essayist, journalist, lecturer and reformer, and his work on metropolitan slums and social life in the city is important in the critiques of particular forms of civil society.

The second text is representative of the recent propensity to join this anxiety of threat to family with a new rhetoric of loss - that of social capital-irrespective of the tensions between the two social structures. While the tendency to join family anxieties with the rhetoric of declining civil society is widespread, former senator and current candidate for the Republican presidential nomination Rick Santorum's book It Takes a Family: Conservatism and the Common 
Good (2005a) is a particularly good example for a combination of practical and locational reasons. First, he most clearly makes the argument that the family and social capital are mutually reinforcing. He tells us: 'Where social capital has disappeared, the breakdown of the traditional family usually was a huge factor in that calamity' (Santorum, 2005a: 10). Second, he used his position as a senator and member of the Republican leadership to provide abully pulpit to promote family values in general, and to promote prominent institutions and figures of the family values advocacy contingent (e.g. Focus on the Family, the Family Research Council, James Dobson and Tony Perkins). ${ }^{2}$ This advocacy extended to the broader religious conservatives' promotion of civil society, like Marvin Olasky's compassionate conservatism project. For instance, he gave a famous speech later adapted as an article, 'The Conservative Future' (Santorum, 2005b), at the Heritage Foundation's First International Conservative Conference on Social Justice in September 2005. After leaving the Senate in 2007, he has continued to tirelessly work on issues of family values as a Senior Fellow at the Ethics and Public Policy Center and as a regular contributor to Fox News. Third, he self-professedly used his elected position and position in the Senateleadership to further agendas founded upon this intellectual and historical confusion. In short, he has tried to make bad social theory the basis of muddled policy.

By disentangling the religious right's contribution to social discourse, I propose to distinguish the similar diagnoses of the two movements family values and social capital - from their contradictory recommendations. The two movements - family values and social capital - both decry a loss of social relations, and both argue that society is better maintained, better facilitated with stronger social relations. Thus far, they reach similar diagnoses. However, the prescriptions are at odds. They fail to distinguish types of social relations, they fail to see how social forms are shaped by historical conditions, and they fail to see contradictions in their respective solutions. The confusion arises because one movement basically identifies modernity as the cause of social ills, while the other believes it to be their cure. In our example from former Senator Rick Santorum, the intellectual muddle reaches its nadir.

Questions about the relationships between family and society have long shaped American social thought. Even so, Robert Putnam mainly ignores de Tocqueville's early 19th-century documenting of American associational life and charts the widespread emergence of this form of civil society during the late 19 th and early 20 th century. ${ }^{3}$ Using his eponymous example of bowling teams, the American Bowling Congress only began as an organization in the first decade of the 20th century and its meteoric rise took place during the two middle decades of the century, peaking in the 1960s. (The Women's Bowling Congress started a little later, in the late 1910s.) The rise of these associations, however, was not a lauded development at the time; clubs and associations - commentators argued - pulled husbands and wives, mothers and fathers, out of the home. Long before bowling alone became a problem, bowling together was one. 
In contrast to Robert Putnam's (2000) praise for bowling teams, early 20th-century observers of the rise of the associational life of civil society (including bowling clubs) thought it threatened community and family life. Putnam's category for these social relations - social capital ${ }^{4}$ - arose from the ruins of community, or so Progressive Era reformers like Riis would have us think (Riis, 1903). The currently lauded associational life of the United States was, in the fin-de-siècle period, thought to be a social ill, because it lured people away from their family. In the waning decades of the 20th century and the beginning of the 2lst, advocates of family values have embraced civil society and social capital as panaceas for threats to the family - the former threat has become the solution.

While civil society has had a brief reign as a dominant social form, its ostensible present decline elicits mourning as if it is the passing of an eternal tradition. ${ }^{5}$ A basic assumption in theorizing civil society - the tension that exists between individual and society - often overshadows a third pole to social tensions: that is, community, another form of collectivity. ${ }^{6}$ The antagonism between community and civil society is not merely a categorical problem of social structures (or forms of relationships, as we shall see). These theoretical distinctions also correspond to historical changes in social life, or at least changes in how social life is discussed and represented. This historicity does not merely relate to distinct manifestations of social relations under different prevailing modes of production. Older tensions or complaints were that the rise of the associational life of civil society specifically threatened other forms of social relations - namely the family.

\section{Modernization and the Family}

The impacts of industrial urbanization on 19th-century social life were transformative. Long-standing ties of people to local communities eroded under pressures and opportunities of urbanizing capital. Large-scale domestic and international migrations sent millions flocking to emerging urban factories. Social relations which were (literally) grounded in place began to fray, and new, more distant (and often instrumental) relations began to replace the much older ties that bound generations to their long-standing homes and communities. Urban commentators described this loss of community, and excoriated the city and the interest relations which were often cultivated there.

Though later than Dickens in England, 'realist', fictional ruminations on the urban poor began in the last decade of the 19th century in the work of Stephen Crane (Maggie, a Girl of the Streets) and William Dean Howells (A Hazard of New Fortunes). These were paralleled by the rise of documentary, muckraking journalism by figures like Jacob Riis, who in 1890 published How the Other Half Lives (1997), drawing upon his journalistic work for the Tribune and the Evening Sun, as well as longer pieces for magazines like Scribner's. This work is the first of those relating to his broader normative project on home and family, which he elaborates further 
in other works like The Making of an American (1925), The Battle with the Slum (1998), The Children of the Poor (1970) and his The Peril and Preservation of the Home (1903). How the Other Half Lives was enormously popular - eleven editions in five years (Szasz and Bogardus, 1974: 422); its success far exceeded Riis's expectations and it had far more impact than earlier works of critique of the newly industrializing cities. He became one of the most prominent spokespersons for social reform.

Riis's broader project focuses on preserving a social order grounded in the middle-class family and legitimated by religion. Essentially - like most Progressive Era reformers - he wants to transform the poor into the imago burgensis. He wants a full-scale adaptation of the style of life without addressing any underlying economic conditions. This mimetic transformation, of course, cannot produce exact replicas; the poor cannot actually afford the lifestyle. Nonetheless, the reformers' hopes are that the financially underprivileged can at least comport themselves with a more genteel air and, most importantly, adapt their family norms. The transformations necessary for this plan are three-fold: a change in the physical structure of the city to create the community, or public, space for home; transforming urban property to produce spaces conducive to family through laws banning certain housing structures, making windows, airshafts, etc. mandatory, that is, creating the domestic, or private, space for home; and, finally, a change in the consciousness of the poor.

While the former two ideally would have included a full-fledged, statesponsored Haussmannization of New York, ${ }^{7}$ Riis realizes that he is no longer in Europe. He will have to rely on the markets to adapt the municipal infrastructure gradually. 'Business, in a wider sense, has done more than all other agencies together to wipe out the worst tenements. It has been New York's real Napoleon III, from whose decree there was no appeal' (Riis, 1997: 201). (Riis would have envied the public/private partnership which restructured New York City a century later to make Times Square 'family-friendly' by displacing the indigent and replacing them with suburban megastores.) For Riis and other fin-de-siècle reformers, business was to provide the necessary urban changes to ensure a middle-class public defended from the urban poor.

The goal of Haussmann and Riis was, of course, a bourgeois self-preservation; Walter Benjamin has pointed out that 'The true goal of Haussmann's projects was to secure the city against civil war' (1999: 12). ${ }^{8}$ Likewise, Riis worried tremendously about the threats to the city and the potential for violence against property - hence his frequent, worried invocation of the Draft Riot, Tompkins Square Riot, Chicago's Haymarket Riot and the Paris Commune.

Thus, Riis's introduction to How the Other Half Lives includes excerpts from a report on the 1863 Draft Riots which concluded that:

'When the great riot occurred in 1863 ... every hiding-place and nursery of crime discovered itself by immediate and active participation in the 
operations of the mob. Those very places and domiciles, and all that are like them, are to-day nurseries of crime, and of the vices and disorderly courses which lead to crime. By far the largest part - eighty per cent. at least - of crimes against property and against the person are perpetrated by individuals who have either lost connection with home life, or never had any, or whose homes had ceased to be sufficiently separate, decent, and desirable to afford what are regarded as ordinary wholesome influences of home and family... The younger criminals seem to come almost exclusively from the worst tenement house districts, that is, when traced back to the very places where they had their homes in the city here.' Of one thing New York made sure at that early stage of the inquiry: the boundary line of the Other Half lies through the tenements. (Riis, 1997: 5, his emphasis)

The fear of this urban explosion informs the need to know the Other Half; reform is a result of fear. ${ }^{9}$ This Manichean split between darkness and light - 'I hate darkness and dirt anywhere, and naturally want to let in the light' - frames Riis's analysis. His concern for the Other Half is how to bring it into the light to best preserve property and family. To maintain the necessary social stability to enable the continuance of the current economic system, Riis advocated not only changing building codes and zoning laws; he was willing to allow real estate profit margins to decrease somewhat while maintaining the structure of investments in property. ${ }^{10}$

The violent potential of the Other Half, as we saw above, was the primary motivation for his concern with social ills. For Riis, the Other Half is a chaos to be tamed, a disorder to be ordered. Riis, like many other reformers of the time, is a prophet of order; ${ }^{11}$ he clings to the venerable social watchwords, "property, family, religion, order. ${ }^{12}$ The poverty, slums and suffering of the city follow from uncontrolled growth with its 'consequent disorder and crowding' (Riis, 1997: 146). Like Napoleon III, he seeks a new way to order the city.

Riis adopts a popular ideal of domestic Protestantism to form a constellation of these first three social watchwords as a model for the fourth. His many books and lectures focus on addressing the modern city to preserve a social order based on property and family legitimated by religion.

\section{Riis and the Christian Home}

In one of these books diagnosing the ills of urban life - originally given as a seminary lecture series - Riis tells his contemporaries that because the modern family does not spend enough time together, neighborhood life has collapsed. The culprit in this violence to the community: the rise of clubs and bowling. The time spent networking was time after one's workday; these clubs drew men and women out of the home. ${ }^{13}$ And the home here was the popular Victorian ideal of the Christian home.

This particularly Protestant articulation of home became the locus for the formation of moral citizens and pious Christians; ${ }^{14}$ it was a sacred space, forming a bulwark to insulate the Victorian family from the ravages of 
modern life and supposed threats from proletarian immigrants. The Christian home ideal not only furnished patriotic and ethical training but also:

provided a means of blessing middle-class values and norms. Domestic Protestantism was not merely an individualized form of popular piety. The ideology promoted by secular and clerical writers helped to justify middleclass notions of gender, economics and taste by presenting the Victorian home as eternal and God-given. (McDannell, 1992: 173)

As the God-given ideal for social life, the Christian home legitimated the family and defended it against the perils of modernization.

This popular idea of a Christian home requires a spatial arrangement for a family order. An ideal of rural or small-town life, which fin-de-siècle commentators thought to be the proper social and spatial formation to foster the Christian home, requires both kinship relations and relationship to place. In the fin-de-siècle period, new zoning laws started to limit the numbers and relations of those who could live in the same residence by foreclosing options like multiple boarders or even older extended-family domestic arrangements. The spatial arrangements carved up private space to promote the formation of what, by the middle of the 20th century, comes to be called the nuclear family. The family does not go nuclear until after the bomb, but the movement towards this category is already under way in broader sociological work. $^{15}$

The influence of a family in a proper Christian home provided the greatest reach of the gospel into society. To order the city, a proper sense of domestic space, relationships, and habits had to be instilled into the urban poor. The Christian home became an ideal of how family life was to be structured. But then this ideal became an instrument of ordering; if home life could be restored to the city, its influence might spread.

In his The Peril and the Preservation of the Home, Riis identifies 'the weak spot, in your campaign for the home - that home which all the influences of the modern day combine to put in peril. I mean the disappearance of the family altar' (1903: 49-50). Two important points emerge in this diagnosis. First, the home is under threat from modern life. He continues to elaborate on this point by delineating some of the causes of the destruction of the home. ${ }^{16}$ But Riis's second point about the family altar is a quite intriguing invocation of the Genesis story of Cain. ${ }^{17}$ While the notion of the 'family altar' may evoke a 1950s Ozzie and Harriet household with Bible readings around the dinner table, the altar was initially a place for the violent slaughtering of an animal (Cain's bloodless offering - of crops from his fields - was unacceptable). While Cain - as the first murderer is an image that distils distinct fears or threats to society, for Riis, Cain represents something more. Over nearly a decade and a half, Riis's works continually invoke the Cain story - in How the Other Half Lives, his contribution to My Brother and I (Riis, 1895), and in the 1903 The Peril and the Preservation of the Home. Riis returns to the Cain story again and 
again to represent a range of threats to family norms; the story is used to symbolize anxieties about domestic arrangements, moral laxity and laziness, especially among the urban poor. For Riis, the responsibility to be a brother's keeper - also from the same Cain story - involves molding the poor in the image of the middle class. The Genesis story, thus, informs both the former (peril) and latter (preservation) formulations.

The family altar (and hearth) become a metonym for family, and civil society organizations and clubs are thought to threaten the family and its symbols. Riis writes:

In the town of which I spoke, there have in the last half dozen years grown up two clubs, one for the men, the other for the women, and I am told that practically they all belong. The result has been the disappearance of pretty nearly all of the pleasant neighborhood life of that day when a man gave his arm to his wife after supper and they went together for a social call upon some neighbor, for a chat, a little music, going home in good season for bed, telling one another that they had had a good time. There are no good times in that town any more - not of that kind at all events. The men spend the evenings bowling at the club; the women meet in committees to plan public improvements. The old time supper has become a later dinner and it is the rarest of all things to find a neighbor 'dropping in' unannounced - so rare that one feels that it somehow is not good form any longer. The family firesides are cold. And the young - I am told that there is a disproportionate number of them growing up idle and useless, if not worse. They have lost their hold, though they do not know it. I am no enemy of clubs, although I know little of them; but, as a substitute for the altar, I will fight them until I die. And I am a great backer of woman's influence in public affairs - it has been good always and everywhere in my sight; but I say to you now that I would rather see, we could better afford, that every club and organization in the land should cease to exist, and every ten-pin alley stand silent and deserted, than that the old home life which centred about the family hearth should go from among us. With it goes that which nothing, no commercial gain, no advance in science or government or human knowledge, can replace. (Riis, 1903: 52-5)

The trope of Cain becomes a carrier for all that is good for the family, as we shall shortly see, as well as the threats to it. ${ }^{18}$ Riis's appropriation of the Cain story furnishes both problem and solution; the same trope, which he deploys elsewhere for other urban threats, ${ }^{19}$ here provides a model for solving urban social problems - treating others as members of the family, that is, being a brother's keeper. The biblical overlay renders modern urban conditions and their remedies as transcendental, suprahistorical concerns. The modern American family becomes a family writ large across history and culture; a particular form of the family becomes a transcendental structure, not one formed by particular social and economic conditions.

In this conceptualization, the family thus transcends any social structure, which leads to confusions in how it relates to community and civil 
society. Part of the problem with the contemporary communitarian movement is the failure to distinguish these two distinct types of social structures, and the frequent collapsing of the discussion of associations into the language of community. ${ }^{20}$ At the turn of the last century, a different question was asked: how could home and family be secure, when evenings were spent with friends in bowling leagues, rather than around the "family altar'? At the time that Robert Putnam charts the beginning of bowling teams (2000: 440), such associations were not regarded as a sign of vibrant civic life but as a symptom of decaying community. Social relations began to mimic capital because capital was shaping them - as Marx said, social capital is both a prerequisite for and result of production. ${ }^{21}$ The organic bonds' were already eroding before these clubs and associations began to emerge. The only people still sharing proximity over years were family members. The family had to be protected. But the bowling teams, clubs and so on pulled members out of the home and thus distended the family. With its fall, commentators like Riis felt, the entire community fell.

Riis thought that recognizing the other as brother could rectify social ills. For him, the mark of Cain appears because of society's failure to recognize that 'I am my brother's keeper'; he felt that the tenement's curse - its mark of Cain - could be lifted by the undoing of this failure. Riis tells us that:

Loving our brother, we shall not have the heart to leave him in the slough ... we shall be cutting off the heritage of sin and sorrow and failure that would blight the to-morrow. We shall have lifted the curse [mark] that was laid upon man for forgetting his brother. (1903: 174)

Creating and participating in the community are solutions for social ills, but the first step is the recognition of the bond with the other. Riis declares that:

I am my brother's keeper, and I am ashamed at last not to own it. That is the key-note of the whole modern reform movement, the new charity, the new school, the social settlement and all; and thank God for it. (1903: 188)

He also notes: "My brother" is the word that has healing from all our social ills' (1903: 185). The other person had to become as a family member, not a connection who was a mere means to an end. Riis, like his contemporaries, feared that community structures centered around the family were collapsing in the metropolis - thus he invoked the Cain story both to represent a buttressing of the family and to delineate threats to it.

\section{Community and Civil Society}

While Riis and other reformers were defending family and community (or neighborhood) life from the perils of modernity, other writers were theorizing these same social changes arising with industrial capital. Social theory 
reflections on civil society began to proliferate over the 19th and into the early 20th century. An implicit Hegelian model of concentric relations grounds civil society in the family; on this reading, the family must be the root institution of society. ${ }^{22}$ The interconnected social structures are the Hegelian series of concentric relations between the family, civil society and the state. In this model, the broader social structures are predicated on the preceding ones - each structure is the building block for the next one. Thus, presumably, without family relations one is not interconnected to civil society and the state. However, most associational life is not mediated through the family - excepting, probably, religion; one usually joins voluntary clubs as an individual. These two social forms - family and civil society - come into tension because their structures are predicated on different expectations about the nature of social relations. Figures like Riis, or the more recent Focus on the Family or Family Research Council, presume that families provide primary relations that are not self-interested. While not necessarily altruistic, these relations are supposedly organic ones of binding sentiment; they are not instrumental but ends in themselves. In contrast, the associational life of social capital is still ultimately about productivity. We need not turn back to Marx for this point, for Robert Putnam's analogy between social capital and other forms of capital makes this explicit.

By analogy with notions of physical capital and human capital - tools and training that enhance individual productivity - the core idea of social capital theory is that social networks have value. Just as a screwdriver (physical capital) or a college education (human capital) can increase productivity (both individual and collective), so too social contacts affect the productivity of individuals and groups. (2000: 18-19)

Social capital increases individual productivity. While the means-ends distinctions between these social relations are more at the level of ideas than empirical reality, the assumption that organic familial relations rather than the transactional ones of voluntary association - will solve presumed social ills underlies the contradictions that we will soon confront in the ideas of Rick Santorum.

Riis's model of a Christian home assumes a family ideal rarely manifested in history. It posits a unity of wills which supposedly arose in small town life. In his autobiography, first published in 1901, Riis acknowledges that for him the slum is still contrasted not with uptown homes of plutocrats but with the countryside.

For hating the slum what credit belongs to me? Who could love it? When it comes to that, perhaps it was the open, the woods, the freedom of my Danish fields I loved, the contrast that was hateful. I hate darkness and dirt anywhere, and naturally want to let in the light. I will have no dark corners in my own cellar; it must be whitewashed clean. (1925: 272) 
I argue that his ideal is closely akin to the theoretical construct of Gemeinschaft. Community was a presumed unity of people and place where families had lived side by side for generations and developed relations in which social life functioned along the lines of family relations. While the point that Riis's description of his childhood home in Ribe, Denmark, resembles Ferdinand Tönnies' idea of community has been made elsewhere (see Fried, 1990: 21), I am making a different point. I am arguing that Riis is trying to create a space for home (as metonym for Gemeinschaft) in the city. Riis wants to create small havens from a heartless world into which people may retreat - he advocates more windows and parks to bring the air and countryside into urban life.

Riis makes pragmatic concessions with regard to repairing the city for the urban populations, unlike other reformers, including those who founded the Children's Aid Society or the Fresh Air Fund, which carted young urban orphans to houses and farms away from the metropolis. Riis's fixes are to bring elements of the country to the city; the country is still the ideal. Among the great achievements of reform, he cites the tearing down of Tompkins Square - the site of an 1870s urban uprising and disdained anarchist movements for 'Bread or Blood' by near-starving laborers - to be replaced by a park. He contends that the introduction of gardens into a tenement block:

does the work of a dozen police clubs. In proportion as it spreads the neighborhood takes on a more orderly character. As the green dies out of the landscape and increases in political importance, the police find more to do. Where it disappears altogether from sight, lapsing into a mere sentiment, police-beats are shortened and the force patrols double at night. (1997: 124; see also Riis, 1903: 184)

Riis recognizes that the city cannot be sent away; it has come so forcibly, it is to remain a feature of the modern world. The family in its Christian home becomes the last urban remnant of small-town life.

This presumption of unity and nostalgia for totality parallels the social shifts described in Ferdinand Tönnies' analyses of modernization. In his argument, the organic totality of community (Gemeinschaft) collapses before the onslaught of this modernization, and thus social existence fragments. Tönnies' Gemeinschaft is an association based on organic life, growing out of a familiar, comfortable and exclusive social existence. His theory of Gemeinschaft assumes a complete unity of wills, that is, a common sense of values, mores and culture. He writes:

[T] he theory of Gemeinschaft is based on the idea that in the original or natural state there is a complete unity of human wills. This sense of unity is maintained even when people become separated. It takes various forms, depending on how far the relationship between differently situated individuals is predetermined and 'given'... While the seed of Gemeinschaft, or 
the bias of human minds towards it, is to be seen in any relationship of kinsfolk, these three [relationships between a mother and her child; between a man and a woman as a couple; and between those who recognize each other as brothers and sisters] are of special importance as containing the seeds which are strongest and most readily nurtured. (Tönnies, 2001: 22)

Though beginning as a community of kinship, Gemeinschaft develops into community of place, and subsequently emerges into community of spirit the community of place binds together life on a physical level and community of spirit holds life together on the level of consciousness. According to Tönnies, home is 'both the physical location and so to speak the living body of kinship' and, beyond the walls of the house, wherever the spirit of kinship is strong in relationships, one is able to feel at home (Tönnies, 2001: 28). ${ }^{23}$

The demands and pace of modern life undermined the potential for such a home for the family. The changes in social life brought about by industrial urbanization had a double relationship to space - the displacing of labor from longtime family homes and then reconsolidating a mass within proximity to the locus of production. ${ }^{24}$ The city, thus, became the locus of the displaced; they were new places teeming (or places newly teeming) with populations who were all from elsewhere, and whose languages, cultures and families were very different. As the site of this random agglomeration of people, the city became juxtaposed to the ideal of smalltown family life; the city became the locus of capital, anomie or Gesellschaft.

The displacement from the small-town Gemeinschaft begins with these modernizing changes. Social structure, Tönnies argues, then transforms into Gesellschaft - a civil society which is a purely mechanical construct. Gesellschaft, too, begins with a group of people living alongside each other but without being united; spheres of power and activity are divided and any confluence of wills is merely transactional. Rather than the Gemeinschaftrelationships of kinship and spirit founded on a bond of blood, with Gesellschaft all relationships are replaced by abstraction. All "conventional sociability may be understood as analogous to the exchange of material goods' (Tönnies, 2001: 65) - all relations are reduced to money (or contractual) relations. With the separation of productive labor from private, domestic labor and the coextensive separation of workplace from home, he argues, a rationalizing process takes place in work practices - breaking processes into constituent parts, changing administrative structures, movement of operations nearer to important markets and so on. The entire social structure comes to exist for the sake of merchants and capitalists. These changes in work displace people from the land; as they move to different places to sell their labor, the tie between kinship and place is severed.

One strand of appropriation of Tönnies in American sociology transforms these social structures into distinct forms of relationships community and civil society become sentiment and interest relations. 
This juxtaposition of family to the instrumentality of interest relations was still a standard idea in mid-20th-century American sociology. At this point, American sociologists regarded the nuclear family as the last bastion of sentiment relations and a bulwark against the increasing threats of modernity.

With Margaret Mary Wood, the discursive connections which, I argue, exist between Gemeinschaft and family, become explicit; we are no longer restricted to our Riisian authorial-biographical read for their connections. Her analysis relies upon Theodore Abel's two categories of social relations: sentiment relations and interest relations. ${ }^{25}$ Abel points out that in his Gemeinschaft und Gesellschaft categories, Tönnies was 'the first to recognize the difference between what we have termed interest and sentiment relations' (1930: 7). ${ }^{26}$ In her appropriations of the sentiment/interest or Gemeinschaft/Gesellschaft distinctions in relations, Wood outlines a history in which the expanding field of interest relations in the United States in the first half of the 20th century coincided with the contraction in that of sentiment relations. These, she argues, are narrowed nearly to the point of the nuclear family. She writes:

The field of the sentiment relationships has, on the contrary, been narrowed. The concept of the family, which is the great fountainhead of the sentiment relationships, has become more exclusive. Generally, only the more immediate kin are now included within the family circle. The obligations of kinship which formerly held the larger inclusive family structure together have ceased to function except among near kin, and even here they tend to be replaced by bonds of a different nature. (Wood, 1960: 23)

The immediate family becomes the last bastion of sentiment and emotion. It is the last haven against a modern world of pure instrumentality. However problematic this vision of the family might be, it enables the inevitable relation between community (Gemeinschaft) and family. The bonds of a different nature, that is, transactional relationships, are those whose rise Jacob Riis lamented; these outside demands drew people away from the family altar. This separation from family, and thus any form of ties of sentiment, is an unnatural aberration (Wood, 1960: 24). Like Riis before her, Wood cannot imagine meaningful relations in the modern world unless mediated through the nuclear family. In this arc from Riis to Wood, the family remains the last bastion of community against transactional, interest relations; the family is the sole haven from the abstract relations of civil society.

\section{Family Values}

The politicization of the family over the last two decades of the 20th century is usually couched in terms of defining the country (see, for instance, Hunter, 1991). The struggle to define America is much older than the 
coming of age of the baby boomers. Culture wars over the class, ethnic, and religious configurations of the nation have been with us at least since Victorian responses to the city and, truthfully, even much longer than that. For the "making of Americans, ${ }^{27}$ Jacob Riis calls for hoary Protestant values of thrift, orderliness, hygiene, hard work and dedication to family. He combined these values with a desire for 'small-town values', a normative assumption of language (English) and expectations of cultural assimilation for the 'other half'. For his prescription for social integration, he has received homage from contemporary figures of the religious right, such as the founder of modern 'compassionate conservatism, Marvin Olasky (see Olasky, 1992, 2009). Riis wrote of the need to preserve the family and home threequarters of a century before James Dobson called for a focus on the family or the Family Research Council gave Reagan administration officials a forum for further politicizing the family. With the rise of the religious right, the previous fin-de-siècle kulturkampf now became an issue of policy. The culture wars spread from the way institutions function and disseminate norms to legislative and executive actions. The tenor of the culture wars took a new pitch.

Riis's writings on the city represent one front in a much larger struggle over American identity in response to modernization - to do with proper types of individual subjects and proper social structures. The 1980s' bubbling up of the politicization of the family provoked realignments on several positions within the different camps involved in the culture wars. Jacob Riis had drawn the lines clearly between the family and civil society - these were antagonistic social structures. Yet contemporary defenders of family values such as Rick Santorum now contend that clubs and associations are good for the family. In a speech given at the conservative thinktank the Heritage Foundation, then Senator Santorum took up the mantle of Olasky's compassionate conservatism, which was popularized by George W. Bush in his 2000 presidential bid. Santorum wrote that: 'Compassionate Conservatism relies on healthy families, freedom of faith, a vibrant civil society, a proper understanding of the individual and a focused government to achieve noble purposes through definable objectives which offers hope to all' (2005b). Civil society, family, faith and the proper form of individuality required a government focused on 'noble purposes. The cultural issues were now the concern of the ballot box.

He locates his project within the broader contexts of compassionate conservatism - the founder of which lauds Riis. Both in his monograph It Takes a Family (2005a) - and in his presentation on the future of conservatism, Santorum links the family with civil society. In his essay, he writes that:

[C] ompassionate conservatism is founded on the family because the family is the foundation of a healthy civil society. Families set standards and demand that their children live up to them. Strong families are grounded in a code of moral conduct, a shared faith, plus judicious use of the age-old 
sanctions of shame and stigma. Families teach us about the essential democratic virtue of selflessness - the mantra of the popular culture, "if it feels good do it,' just doesn't wash in a family. (2005b)

Here, again, the family embodies selfless sentiment relations; it is the locus into which we may retreat from the instrumentality of civil society's interest relations. And yet, the family is to be the foundation of this same civil society.

Santorum's project rests on the assumption that the 'traditional family', that is, the bourgeois nuclear family, is the foundation of every successful civilization (Santorum, 2005a: 7). Ignoring all anthropological or historical evidence which might suggest the modernity of this 'traditional' social form, Santorum argues that there are five different types of capital in American civil society and that 'family breakdown - out-of-wedlock births, divorce, cohabitation, and absentee parenthood - has depleted that capital in recent decades' (2005a: 9). ${ }^{28}$ Santorum (2005a: 55) creates a liberal bogeyman by falling back on rather banal clichés of individual (the concern of liberals) versus society (the concern of conservatives), arguing that liberal social goals fail to recognize the bonds between individuals. My argument, however, does not fall on the false dichotomy of the individual-society binary; rather, I contend that the structure of the social bonds between individuals matters. All bonds are not the same. The structures of community are not the same as those of civil society. The bourgeois subject and the ostensible Gemeinschaft-type sentiment relations found in the nuclear family represent the proper form of individual subject and social organization for Riis; for Santorum, the family becomes but a cog within the machine of capital.

Santorum undertakes his discussion of social capital with a brief summary of Robert Putnam's work Bowling Alone. Putnam describes social capital thus:

[S]ocial capital refers to connections among individuals - social networks and the norms of reciprocity and trustworthiness that arise from them ... 'social capital' calls attention to the fact that civic virtue is most powerful when embedded in a dense network of reciprocal social relations. (2000: 19)

By erecting his argument on the erroneous edifice of Putnam's arguments, Santorum replicates Putnam's mistaken assimilation of communitarian rhetoric to the structures of civil society. By collapsing these structures, Putnam provides Santorum with an intellectual framework that reinscribes the individual versus society. All bonds are reduced to the instrumental ones of civil society.

The confusions do not solely emanate from the religious right; they are prevalent in the scholarly circles of those advocating social capital, where one finds rhetoric of community being conflated with that of associational life. Even beyond his book's subtitle - 'The Collapse and Revival of 
American Community', Putnam tends to collapse the two social forms into each other, as we have seen. For instance, Putnam tells us that:

'Social Capital' is to some extent merely new language for a very old debate in American intellectual circles. Community has warred incessantly with individualism for preeminence in our political hagiology. (2000: 24)

Or:

It is emphatically not my view that community bonds in America have weakened steadily throughout our history - or even throughout the last hundred years. On the contrary, American history carefully examined is a story of ups and downs in civic engagement, not just downs - a story of collapse and of renewal. (2000: 25)

In the first quote, Putnam juxtaposes the individual to society, whatever the social structures may be; and in both, community and civil society (or civic engagement or social capital) are used interchangeably.

Putnam wants to see an array of social relationships - the household and the family, the community and social networks - as operating in modes of mutual reinforcement, while Riis sees the latter turning against the former. Writing on the impacts of urbanization in contemporary Dakar and Johannesburg, AbdouMaliq Simone (2001) argues that the relationships between family, communities and broader social networks turn from mutual trust to antagonistic competition with a foreclosure of life chances. ${ }^{29}$ Riis's analyses of tenement life document the 75 percent of the slum-dwelling, urban population for whom life chances are minimal and minimizing. He reports that the proletarianization of the new immigrants from Europe is indeed increasing tensions and leading to competition, but he most fears the inter-class (rather than intra-class) strains. Yet some of these intraclass competitions are already implicit within the Riisian accounts - some of them through the enforced alienation of labor. ${ }^{30}$

Compared to the turmoil of Riis's fin-de-siècle city, Putnam's golden age of social capital (post-war America) was a period of unprecedented economic growth, the nadir of American immigration - lowest levels since the 1820 s - suburbanization and the rise of the nuclear family. In other words, Putnam writes about a time and place of relative social stability and the expansion of life chances; he then ahistorically assumes that the structure of relations should be the same for all periods. (Simone makes clear the necessity for establishing the historical and social contexts of social capital - a lesson which Putnam would do well to note.) Riis's and Simone's assessments of agonism, however, reflect times/places undergoing not a mere social change but an anomic overturning of norms, ${ }^{31}$ periods in which shifts of the role of capital completely alter not only the basis of social reproduction but also threaten the ideological apparatuses that legitimate these norms. 
Riis was trying to legitimate the (soon-to-be) nuclear family and maintain an economic system which created the public/private split that enabled the formation of this family. To do so, he isolates the family from the broader network of social relations to bracket it from any competitive social life and thus to enable familial affiliation, trust and loyalty to flourish. He is creating a haven safe from the associational life of social capital with the hope of re-establishing social norms thought to flourish in rural communities. Simone (2001: 46) talks about the roles of networks in a move toward 'normalization' of economic management and governance in global urban contexts. Riis, too, looks at social relations as the means for negotiating urban industrialization to re-establish some form of norms. However, he disputes the structure of those relationships. He argues for the "naturally given' form of the family.

The naturalness of the family is, of course, a figment of Riis's (and Santorum's) imagination - it, too, is an institution formed through processes of institutionalization. In the discursive shift from Riis's to Santorum's family, the acts of institutionalization of this social form are exposed. Bourdieu has pointed out that social networks (even the family) are 'not a natural given, or even a social given, constituted once and for all by an initial act of institution' (Bourdieu, 1986).

In his 'Forms of Capital', Bourdieu implies that social capital is imbricated with the habitus of those constituting the network of social relations. Margaret Somers points out that this assimilation "produces a theory less about how social connections can be owned, than about how one is more commonly owned by, that is, possessed by, social capital' (2008: 226). The associations of social capital thus act on individuals and provide norms to be internalized. While Riis also desires an interpellation for those subjects being created through exposure to bourgeois norms, he calls for a distinct social institution (or apparatus) - the family. Santorum also focuses on the family, but he looks outside it to what he calls value-transmitting institutions to enable the formation of subjects and social relations, that is, for him social capital is equally an important determinant of a habitus. For Santorum these social bonds form identities that can help form families, while for Riis the family must be protected from these other social relations.

These relations and the reciprocity arising from the bonds form the crucial first of Santorum's five pillars of American civilization. He argues that where the family breaks down, social capital crumbles. Yet, while his account initially claims that the traditional family undergirds each of these pillars, ${ }^{32}$ Santorum appears to reverse the direction of causality with his discussion of Putnam. Initially, families had to be repaired and nurtured to build and support social capital. Now he finds that:

we need an abundant store of social capital to create and sustain the kind of freedom that our founding fathers envisioned, the kind of freedom that promotes the common good and supports families. It's a freedom requiring a certain degree of selflessness and virtue. (2005a: 56) 
Social capital creates modes for transmission of values to foster the family. Strong families are necessary for social capital, but we need the freedom which arises from social capital to support families. (A Nietzschean confusion of cause and effect - or perhaps a false causality - appears to be at play here; see Nietzsche, 1968.) He tells us that 'the place to begin in building up social capital is with the family' (2005a: 57), but how then does the proper form of freedom exist to support the family?

[W] hile the number of Americans who went bowling for recreation was higher in the 1990s than in the 1950s, the number of Americans participating in bowling leagues had declined markedly over the same period.

Now, that may sound trivial, but think what that kind of statistic means. A bowling league is an association; joining means agreeing to change your personal, individual life - for example, by agreeing to show up for games every Monday night, whether it is convenient or not - for the sake of others, who rely on you to show up... . The thing of huge significance to all Americans is that the decline of bowling leagues is but one of countless examples revealing that Americans over the past generation have given up on the habit of joining, the habit of association. Now, we still sometimes go bowling, but only on our terms, as the fancy strikes us - which means we go bowling alone. Most often, however, we just stay home and watch TV, alone. We have gone from being a nation of reliable joiners to a nation of individuals jealously guarding their 'free time,' the time when no one has a claim on them. We are not renewing our social capital. (2005a: 54-5)

The idea of 'joining' is entirely at odds with the familial ideals from Tönnies to Riis to Wood - one does not join a family (excepting by marriage) but rather is born into it. The family ideal assumes an organic naturalness, and this organicism is to be the basis of social relations, not the artificial transactions based on capital that require joining.

Santorum's project of compassionate conservatism ties the interests of the family to those of civil society, albeit with confusions about how they relate to and support each other. His insistence on the transcendental structure and role of the nuclear family requires an obfuscation or elision of the historical antagonism between the family and civil society; the pleas of compassionate conservatism's predecessor - Jacob Riis - must remain in obscurity to argue for the mutual fecundation between these two social structures. To draw together these two forms, despite the historical and theoretical tensions between them, Santorum makes a subtle change in his argument.

\section{Gemeinschaft, Gesellschaft and the Family}

Santorum calls for the defense of a different institution than Riis. This family of the new millennium attempts to keep the form of family without the same internal principles structuring it. Implicit is a sense that there has been a foreclosure of the sentiment relations of Gemeinschaft - it 
becomes irretrievable. The family, which was articulated as its last remnant, no longer seems to exist; it has to have a new means to bolster it. The exhortations for protection of the family from policy and legislation inserts instrumentality into the institution of the family - it has become, in Tönnies' sense, a Gesellschaft structure. The collapse between the movements of family values and social capital marks a second acquiescence - the family has been irredeemably changed by modern life. The family of the family values movement is a shell institution from which the previous content has been emptied.

As the family itself transforms, Santorum can argue that to restore the five pillars of capital we must start with the family ${ }^{33}$ - all forms of capital, he argues, are grounded in the family. He inverts the Riisian claims that capital (and its social versions) was the cause of family breakdown. He among others - reconstitutes the family as a modern political institution; the means of addressing the anxieties about family values are thus at odds with the language of family. At the discursive level, the family values movement is a partial rejection of modernity, or at least the impacts of modernization. With this movement, the older social form of family, or Gemeinschaft, is to be a bulwark against the onslaught of modernization. ${ }^{34}$ Whereas the prescription of social capital implicitly recognizes the sufficiency of modernity to solve its own problems - a modern social form of Gesellschaft can be the panacea for social problems. By integrating the family into the concerns about social capital, Santorum drops the critique of modernity from the concerns surrounding the family.

Since anxieties about the family are no longer integrated with critiques of modern civil society, they are able to take up new means for redressing concerns. Riis's attempt to bring the countryside to the city and set limits on capital are not the responses of Santorum - he calls for an embrace of capital. The religious right is very much a political movement and, as such, grounded in instrumentality. The primarily evangelical movement ${ }^{35}$ has to legitimate its decision to shed its centuries-old commitment to a Troeltschian sectarianism vis-à-vis the state. ${ }^{36}$ The de facto withdrawal from concerns of temporal power has been foresworn through the classic moves of ressentiment-politics. With the decline of unions and other voluntary life, religious institutions remain the sole locus of vibrant social capital. The religious right has a comparative advantage over its political opponents because of this in-built infrastructure into which it can tap. Thus, it assimilates social capital to its political goals of 'family values', however ambiguously defined.

But the functioning of the religious right is not our concern here. The assimilation of family values rhetoric to the concerns of social capital signals a rapprochement between social conservatism and modernity. As economic shifts push the nation into a globalized, postmodern culture, middle-class angst no longer harks back to the simple times of Gemeinschaft ideals. It is too remote a past to be viable; thus, there is an acquiescence to modernity. The modern family values movement spurns its Victorian roots by 
maintaining the nostalgic language for a life and family of old, built around a Christian home, while embracing means, institutions and - even more importantly - a form of family which belie the nostalgia. The torch-bearers of the family have transformed the family ideal. Most of the long-time compatriots in this cause have abandoned the nostalgia in all but rhetoric, while embracing the language as a means for political power. The family is now but a remnant of the social institution which it once was, but this shrinking has taken place at the hands of its defenders.

American modernization is now not so very new; its problems have been negotiated for well over a century. The social problems created through the urbanization of industry - once so worrisome to Jacob Riis - are no longer present; de-industrialization and the subsequent loss of urban job opportunities (and life chances) now loom much larger. Yet, as we have seen, the basic concerns about modernization's downsides have continued into our current political debates. As the industrializing spatial fixes, which created the extreme growth of the late-19th-century city, began to fracture with the geographical separation of production and consumption, modern life irreparably changed. From a loss of inner-city jobs to a culturalization of politics, the changes in capital and its relationships with the American city have changed the conditions for the discussions of the modern family.

This movement of family anxieties into the realm of policy is part of a broader political trend over the last several decades - a culturalization of politics. This process is evident as early as Riis's invocations of the trope of Cain. Yet, Riis used cultural means to represent new social conditions not well understood, while Santorum and others deploy religious themes in a movement away from discussing urban social problems. In part this trend was abetted by the geographical removal of much industrial production from the continental United States. This removal undercut the mobilizations of labor and exported many of the social problems which come from production. Despite these changes in political economy, the elevation of the family to a policy concern indicates a giant shift in the nature of the anxieties about the family. The family has now become an institution or association, which can be sustained through instrumental interventions; it is no longer the organic sentiment relations remaining from some long-faded Gemeinschaft. The family and the Christian home ideal which were at the center of American critiques of modernization have ceased to be. The rhetorical integration of concerns with family values and waning social capital becomes possible with the disemboweling of the Victorian ideals of the Christian home. The new contemporary incarnation of the family has become an empty signifier readily deployed for political means; it has become a thoroughly modern institution and lost any claim to transcendence once posited by the late Victorian forebears of the family values movement.

While contemporary debates over family values imply a transcendence of this social structure, the instrumentality of the policy goals belies it. The family becomes a social institution supported by tax, policy, judicial and educational interventions - it becomes an institution reproduced through, 
bolstered by and defined by the state. It becomes a state apparatus, while claims of transcendence legitimate it. Beyond a Horkheimian cultural lag, the American family values debates and cultural wars of recent decades have established a cultural drag. ${ }^{37}$ A cultural drag is a purposive effort to deny change in order to reify the institution, while simultaneously lauding or trying to accrue the benefits of the economic shifts. Cultural drag is an effort to divide cultural politics from political economy. The contemporary debates about family are not a failure to recognize structures changing through shifts in means of production and consumption; they are attempts to historically freeze the family and assert its transcendence, so the seeming benefits of neoliberal capital continue to flow, ostensibly with no impact on the social form.

The politicization of the family at the ballot box and in the courthouse, boardroom and legislative chambers has, over the last decade and a half, played out with the dual approach of transcendental rhetoric and instrumental interventions. In Jacob Riis's Progressive Era, the state's concerns about the family focused on the external frameworks necessary to provide the family with a private space to thrive. The state used zoning laws, building codes and urban planning to enable the creation of a familial haven from the heartless world; it literally created the spaces for privacy. In our present moment, the family values movement calls for the extension of the state through the virtual walls of privacy to structure what the family itself looks like (not merely to change the structures which enable the family). A seeming given of earlier eras - families grounded in heteronormative marriage as the culturally legitimate form of social reproduction - is now fought for.

From the 1996 Defense of Marriage Act (DOMA) to California's 2008 ballot initiative Proposition 8 - which declared that 'only marriage between a man and a woman is valid or recognized in California' - the debates about family life reach into previously private enclaves. Some states have struck at the historical familial norms by allowing same-sex marriage or civil unions, prompting reactions from family values activists with state referenda and legal challenges. In July 2010 the United States District Court in Boston struck down the DOMA as unconstitutional, setting the stage for appeals up to the Supreme Court and an eventual federal ruling on what constitutes marriage. ${ }^{38}$ Responding to this ruling, a Senior Fellow at the Family Research Council reasserts that the current idea of marriage and family has 'been around forever' (Goodnough and Schwartz, 2010); he maintains the rhetoric of transcendence as the movement readies for continuing judicial challenges. No longer the Riisian locus of withdrawal from the world, the family is now a thoroughly public political institution.

\section{Notes}

1. For instance, see Santorum (2005a). Like former senator Santorum, I primarily use the popular work of Robert Putnam for my discussions of social capital.

2. Focus on the Family was founded in 1977 by psychologist and family counselor James Dobson. Dobson was also involved in setting up the Washington, DC-based 
Family Research Councilin 1983; itsfirst two directors-Gerry Regier and Gary Bauer - were former Reagan administration officials.

3. See the appendix in Putnam (2000), charting the rise of prominent associations and clubs.

4. Putnam is not the first to discuss social capital but was the primary force behind its popularization. Pierre Bourdieu, James Coleman and others wrote on social capital before Putnam. For example, see Bourdieu (1986), Coleman (2000).

5. American involvement with voluntary associations has waxed and waned. However, I am not positing the demise of civil society; rather, I am analyzing how concerns for social capital have been assimilated to those of family values. For instance, former Senator Rick Santorum considers the nation's civic structures to be at a critical point. 'In many respects, the problems we now face represent a more complex challenge, because almost all aspects of our civilization seem to be at tipping points. The good news is that capital can be replenished' (Santorum, 2005a: 12).

6. In her recent, critical treatment of social capital, Margaret Somers juxtaposes it with civil society. In an ahistorical manner, she considers civil society to be a social sphere exempt from the characteristics of contractualism associated with social capital. However, Somers' own recitation of the history of the concept of civil society, from Locke, through Hegel, Marx and others, acknowledges that it has long been regarded as having a contractual/transactional nature. For most of the history of the concept, civil society is the contractual form of the social juxtaposed to the non-contractual idea of community. She reifies a brief 20th-century version of civil society conceived as non-contractual as the basic characteristic of the concept and thus erroneously juxtaposes it to social capital, which is its current incarnation (see Somers, 2008).

7. '[New York] has often sadly missed a Napoleon III, to clean up and make light in the dark corners' (Riis, 1997: 199). In the early 1850s, Baron Haussmann was commissioned by Napoleon III to modernize Paris. He built large avenues and shopping districts. In part, the goal was to break up the poor, working-class neighborhoods in which the uprisings of 1848 began. The wider streets would both facilitate troop movements and make barricade-building more difficult for those hoping to start future uprisings. The changes implemented by Haussmann transformed the urban landscape and scattered the poor from the previously overcrowded, labyrinthine neighborhoods to build the modern, bourgeois Paris of wide avenues and open spaces.

8. For example, in Riis: 'Clearly there is reason for the sharp attention given at last to the life and the doings of the other half, too long unconsidered. Philanthropy we call it sometimes with patronizing airs. Better call it self-defence' (1970:1-2).

9. To quote Riis (1997: 5):

Long ago it was said that 'one half of the world does not know how the other half lives.' That was true then. It did not know because it did not care. The half that was on top cared little for the struggles, and less for the fate of those who were underneath, so long as it was able to hold them there and keep its own seat. There came a time when the discomfort and crowding below were so great, and the consequent upheavals 
so violent, that it was no longer an easy thing to do, and then the upper half fell to inquiring what was the matter. Information on the subject has been accumulating rapidly since, and the whole world has had its hands full answering for its old ignorance.

10. For instance, see Riis (1903: 130, 1997: chs 24 and 25, et al.).

11. For more on the importance of order to Progressive Era reformers see Wiebe (1967).

12. Karl Marx calls these the catchphrases of the old society. They were the slogan for the conservative alliance formed between Catholic and monarchist elements in 1848 France; this group was sometimes called the Party of Order (see Marx, 1974: 155). Louis Bonaparte and his reactionary program of order, such as Haussmannization, were lauded by Jacob Riis as a model for how to respond to the problems of urbanization.

13. Writing on a different context but similar time period to Riis, subalternist Partha Chatterjee (1999) outlines how the modern outer/inner distinction took on a material/spiritual overlay in the Bengali colonial context. Colonial nationalist writers, according to Chatterjee, argued that Europeans failed to colonize the inner, spiritual realm. Riis is making a similar argument for the Christian home - it should be a domain unable to be reached from the ravages of urbanizing capital.

14. Colleen McDannell, who has undertaken several studies of the Christian home, describes its central importance as a social institution.

During the nineteenth century, good family life was seen as the means by which the nation and its religion were maintained. Americans believed the home to be the nursery of both patriotism and piety. Home life taught the mutual dependence and reciprocal responsibility of each citizen. By connecting the individual to the community at large, the family instilled notions of morality, order, stability, education, purity, refinement, and discipline. Although the church also played an important role in creating good Christians, the Victorian preoccupation with the family saw home life as the more crucial purveyor of ethics and piety. (1992: 164)

15. The category of the nuclear family first appears in the mid-century work of anthropologist George Peter Murdock (see Murdock, 1949).

16. To quote Riis (1903: 50):

They are many and complex in the setting forth of them, I suspect: the hurry of our modern life, the new freedom that makes little minds think themselves bigger than their maker, the de-moralization of the public school, the pressure of business, - it is hard to get the family together - which is merely setting up the fact of the scattering of the home in the defense of it. The causes are many, but the result is one: the wreck of the home.

17. First, the Cain story is the first place where family devotions and an altar are established. Second, popular commentaries of the 18th and 19th centuries, for 
example, Matthew Henry's Commentary (Henry, 2008), relate Cain's actions to shunning of the family and the altar.

18. For more on the significance of Cain for Riis and other Progressive Era reformers, see Webb (2007).

19. For instance, in his most famous book, How the Other Half Lives, Riis opens his analysis of the Other Half (after a brief introduction) with a discussion of the origin of the tenement. He writes that '[t]he first tenement New York knew bore the mark of Cain from its birth' (1997: 9).

20. For instance, Robert Putnam erroneously equates social capital with community. "Sometimes "social capital," like its conceptual cousin "community," sounds warm and cuddly' (2000: 21).

21. In Capital volume 3, Marx (1993) analyzes the social character of capital in which these social relations both enable production and result from it.

22. This model implicitly assumes the Aristotelian family as a household economic unit that facilitates domestic interactions with society. The family of Riis and other reformers is a modern bourgeois family, which is a repository of affect and seemingly unrelated to and independent of processes of production. The contemporary incarnation of the family in the family values movement maintains the Riisian rhetoric of affect, while returning to contractual, transactional models of familial norms.

23. He continues:

[t]he spirit of kinship is certainly not limited by the walls of the house or by mere physical proximity. Wherever it is strong and lively in the most intimate relationships, it can find its own nourishment, feeding upon past memories and recalling close-knit communal activity, however far it may be from home. In such circumstances we cleave to physical closeness all the more, because only in this way can our longing for love find rest and harmony. The ordinary man, in the long term and for the most part, will feel at his best and happiest when he is surrounded by his family and his own circle. He is at home (chez soi). (Tönnies, 2001: 28)

24. The rise of the modern city is closely tied with a series of demands of capital for spatial fixes. Urbanization consolidated different functions within close proximity; the consolidation of labor, production, distribution, consumption and finance within a circumscribed space increased the efficiencies of capital and thus produced a boom of industrial cities with an overaccumulation of labor to enable wages to remain low. For more on the urbanization of capital, see Harvey (1989).

25. Wood explains these distinctions thus:

In the category of interest relations the selection of contacts is made from the point of view of the service the relations may render toward the realization of some dominant interest; thus such relations are means to other ends rather than ends in themselves. For example, considerations of personality, group membership, and social status are of secondary importance in business relations, relations between employer and employee, lawyer and client, and so forth. On the other 
hand, relations in which sentiment takes the place of calculation are ends in themselves. They comprise the great number of relationships in which the satisfaction of the desire for affectionate response is the main purpose. They are characterized by intimacy, mutual attachment, and sympathy. Such, for example, are the relationships established in acquaintance, friendship, and love. (1960: 10)

26. Abel steers slightly aside from entirely mapping sentiment relations onto Gemeinschaft by arguing that he grounds them in a 'consciousness of kind' rather than Tönnies' Wesenswille. For our purposes, however, this distinction is irrelevant. First, Wood does not go into it - she does not even mention Tönnies. Second, it is these basic social relations and not their grounding which is crucial to Wood's analysis. Abel acknowledges that the basic distinctions in these relations are those of Tönnies.

27. As we have noted, Jacob Riis entitled his autobiography The Making of an American.

28. His 'five pillars of American civilization' are social capital, economic capital, moral capital, cultural capital and intellectual capital (Santorum, 2005a: 10).

29. According to Simone (2001: 49-50):

Households, extended families, social networks or neighbourhoods are increasingly uncertain as to what is constraining their life chances, and, as a result, they must pay attention to other realities, with which they once co-existed only at a 'distance'. But as these realities are increasingly viewed as salient there may be concomitant narrowing of the field of social affiliation, loyalty, trust and co-operation. Different groups operating in close proximity are often forced to become competitors in what are, for the most part, shrinking economies and public domains.

30. In The Peril and Preservation of the Home, Riis tells of meeting with a 'respectable Christian' garment business owner who explains that his business plan is predicated upon a policy of alienation. The owner presents his plan for division of labor not for purposes of efficiency but for the purpose of exploiting worker ignorance to keep wages down and to prevent worker attrition. He purposely requires that each sewer have one specialty and makes sure that his sewers do not know each other - the garment sections are sewed in homes, so the workers do not come together in a factory. Thus, no one knows the entire process of assembling a garment, and he, thus, protects his interest by ensuring that the employees cannot leave him to make garments on their own (Riis, 1903).

31. American sociologist Robert Merton distinguishes between a strong and weak anomie - acute or simple in his terms. The weak is "the state of confusion in a group or society which is subject to conflict between value-systems, resulting in some degree of uneasiness and a sense of separation from the group', while the acute is a 'deterioration and, at the extreme, the disintegration of value-systems, which results in marked anxieties' (1963: 163). The social conditions about which Riis is writing definitely fall into the latter category.

32. For instance, see Santorum (2005a: 10) quoted above.

33. 'It will come as no surprise that I believe the place to start in restoring these pillars of our society is with the family - because the family is at the center of all the types of capital I've just described' (Santorum, 2005a: 12). 
34. Of course, despite the transcendental claims posited by the family values movement, the nuclear family is also a historical form which arose with the bourgeoisie.

35. Senator Santorum represents the social conservativism alliance between evangelicals and Catholics. With long-standing traditions of subsidiarity from Catholic social teaching, the Catholic Church is easily integrated into a concern with civil society.

36. The German liberal Protestant thinker Ernst Troeltsch wrote at the turn of the last century about sectarianism as a relationship of a church to broader society (see Troeltsch, 1992). Sects were those religious groups which had thought that the dominant church groups were in some way corrupt or diminished in their accommodation of broader society. They usually had an element of withdrawing from broader political and civil life and were strong advocates of a staunch church/state separation.

37. Max Horkheimer's analysis of family looks not only to the immediate impact of production on social forms but how cultural forms, like family, remain connected to older modes and thus lag in changing to reflect current economic circumstances. Because of this cultural lag, these slower-changing institutions, like the family, can sustain a form and rhetoric that reflects older economic conditions (Horkheimer, 1999).

38. I do not mean to conflate marriage and family here. I cite this example because it is where the family values movement has focused recent political efforts. The Supreme Court has, of course, in earlier cases made rulings about marriage and family. For instance, in 1967's Loving v. Virginia, the court ended anti-miscegenation laws, allowing mixed-race marriages and families. And in Turner v. Safley in 1987, the Court extended the right to marry by striking down a law requiring prison inmates to have the permission of a warden to marry. In this latter case, the court spelled out a number of reasons for marriage but did not address the question of family composition - a question most likely to be addressed after an appeal of the recent US District Court ruling on DOMA.

\section{References}

Abel, T. (1930) 'The Significance of the Concept of Consciousness of Kind', Social Forces 9(1): 1-10.

Benjamin, W. (1999) The Arcades Project, trans. H. Eiland and K. McLaughlin. Cambridge: The Belknap Press of Harvard University Press.

Bourdieu, P. (1986) 'The Forms of Capital', in J.G. Richardson (ed.) Handbook of Theory and Research for the Sociology of Education. New York: Greenwood Press, URL (consulted April 2010): http://www.marxists.org/reference/subject/ philosophy/works/fr/bourdieu-forms-capital.htm.

Chatterjee, P. (1999) 'The Nation and its Fragments', in The Partha Chatterjee Omnibus. Delhi: Oxford University Press.

Coleman, J. (2000) 'Social Capital in the Creation of Human Capital', in E.L. Lesser (ed.) Knowledge and Social Capital: Foundations and Applications. Woburn, MA: Butterworth-Heinemann. 
Crane, S. (2001) Maggie, a Girl of the Streets, and Other New York Writings. New York: The Modern Library.

Fried, L. (1990) Makers of the City. Amherst: University of Massachusetts Press. Goodnough, A. and J. Schwartz (2010) 'Judge Topples U.S. Rejection of Gay Unions', New York Times, URL (consulted July 2010): http://www.nytimes.com/ 2010/07/09/us/09marriage.html?pagewanted=1\&emc=etal.

Harvey, D. (1989) The Urban Experience. Baltimore, MD: Johns Hopkins University Press.

Henry, M. (2008) Matthew Henry's Commentary on the Whole Bible. Peabody, MA: Hendrickson Publishers.

Horkheimer, M. (1999) 'Authority and the Family', in Critical Theory: Selected Essays, trans. M.J. O’Connell. New York: Continuum.

Howells, W.D. (2002) A Hazard of New Fortunes. New York: The Modern Library. Hunter, J.D. (1991) Culture Wars: The Struggle to Define America. New York: Basic Books.

Marx, K. (1974) 'The Eighteenth Brumaire of Louis Bonaparte', in Surveys from Exile: Political Writings, vol. 2, ed. D. Fernbach. New York: Vintage Books.

Marx, K. (1993) Capital: A Critique of Political Economy, vol. 3, trans. D. Fernbach. New York: Penguin Classics.

McDannell, C. (1992) 'Parlor Piety: The Home as Sacred Space in Protestant America', in J. Foy and T. Schlereth (eds) American Home Life, 1880-1930: A Social History of Spaces and Services. Knoxville: University of Tennessee Press.

Merton, R. (1963) Social Theory and Social Structure. Glencoe, IL:The Free Press. Murdock, G.P. (1949) Social Structure. New York: Macmillan Co.

Nietzsche, F. (1968) Twilight of the Idols and the Anti-Christ, trans. T.J. Hollingdale. New York: Penguin.

Olasky, M. (1992) The Tragedy of American Compassion. Washington, DC: Regnery Gateway.

Olasky, M. (2009) 'Giving that Worked', World Magazine, URL (consulted March 2009): http://www.worldmag.com/articles/15070.

Putnam, R. (2000) Bowling Alone: The Collapse and Revival of American Community. New York: Simon and Schuster.

Riis, J. (1895) 'The Problem of the Children', in My Brother and I: Selected Papers on Social Topics, ed. A.J.F. Behrends et al. New York: Hunt and Eaton.

Riis, J. (1903) The Peril and the Preservation of the Home: Being the William L. Bull Lectures for the Year 1903. Philadelphia: George W. Jacobs and Co.

Riis, J. (1925) The Making of an American. New York: The MacMillan Company.

Riis, J. (1970) The Children of the Poor. New York: Garrett Press Inc.

Riis, J. (1997) How the Other Half Lives: Studies among the Tenements of New York. New York: Penguin Books.

Riis, J. (1998) The Battle with the Slum. Mineola, NY: Dover.

Santorum, R. (2005a) It Takes a Family: Conservatism and the Common Good. Wilmington, DE: ISI Books. 
Santorum, R. (2005b) 'The Conservative Future: Compassion', Townhall. com, URL (consulted December 2008): http://townhall.com/columnists/ RickSantorum/2005/11/17/the_conservative_future_compassion.

Simone, A. (2001) 'Between Ghetto and Globe: Remaking Urban Life in Africa', in A. Tostensen, I. Tvedten and M. Vaa (eds) Associational Life in African Cities: Popular Responses to the Urban Crisis. Stockholm: Nordic Africa Institute. Somers, M. (2008) Genealogies of Citizenship: Markets, Statelessness, and the Right to Have Rights. Cambridge: Cambridge University Press.

Szasz, F. and R. Bogardus (1974) 'The Camera and the American Social Conscience', New York History 55(4): 409-36.

Tönnies, F. (2001) Community and Civil Society, trans. J. Harris. Cambridge: Cambridge University Press.

Troeltsch, E. (1992) The Social Teaching of the Christian Churches, vols 1 and 2, trans. O. Wyon. Louisville, KY: Westminster John Knox Press.

Webb, P. (2007) 'Anti-Semitic Roots of Homelessness: Myth, Exile and Radicals in American Homelessness,, pp. 39-60 in M. Liepach, G. Melischek and J. Seethaler (eds) Jewish Images in the Media. Vienna: Austrian Academy of Sciences Press.

Wiebe, R.H. (1967) The Search for Order: 1877-1920. New York: Hill and Wang. Wood, M.M. (1960) Paths of Loneliness: The Individual Isolated in Modern Society. New York: Columbia University Press.

Philip Webb is a Visiting Lecturer in the Department of History at the University of Oklahoma. His research focuses on social and cultural negotiations of urbanization, theorizing the city and the roles of myth in discursively negotiating modernization. He is currently completing a manuscript on the role of myth in the American discourse on homelessness and has begun a new work that turns a critical eye on the basic categories of urban studies to explore the impact of globalizing changes on notions of space, time and citizenship in new urban structures.

[email: philipwebb15@gmail.com] 